\title{
Natural history of bacteriuria in women with primary biliary cirrhosis and the effect of antimicrobial therapy in symptomatic and asymptomatic groups
}

\author{
P Butler, J M T Hamilton-Miller, N McIntyre, A K Burroughs
}

\begin{abstract}
Primary biliary cirrhosis (PBC) patients have an increased incidence of recurrent urinary tract infection compared with patients with other chronic liver diseases. The course of significant asymptomatic and symptomatic bacteriuria in women with PBC was evaluated: consecutive patients were screened for bacteriuria at their outpatient appointments. Bacteriuric patients who were asymptomatic $(n=21)$ were randomised to receive antimicrobial therapy $(n=11)$, or no therapy $(n=10)$. Bacteriuric patients who were symptomatic $(n=13)$ were treated. All were followed up by weekly dipslide examination of urine. The course of bacteriuria in the 13 symptomatic and 11 asymptomatic treated patients was similar in terms of the medium interval between successive infective episodes (three and four weeks respectively), the number of relapses (six and seven) and reinfections (14 and 18). Most untreated asymptomatic patients became abacteriuric spontaneously but became reinfected with a different organism during the study period. A separate group of 24 PBC patients with no previous bacteriologically proved urinary tract infection was followed weekly in a similar fashion: seven (29\%) became bacteriuric for two to four weeks during a three month period. This study suggests that treatment of recurrent bacteriuric episodes in PBC patients does not alter the natural history of their infection. The long term implication of periodically infected urine in these patients is currently unknown.
\end{abstract}

(Gut 1995; 36: 931-934)

Keywords: primary biliary cirrhosis, urinary tract infection.

P Butler

N McIntyre

A K Burroughs

and Department of Medical Microbiology J M T Hamilton-Miller

Royal Free Hospital and School of Medicine, London

Correspondence to: Dr A K Burroughs, Dr A K Burroughs, Transplantation Unit, Royal Free Hospital, Pond Street, London NW3 2QG.

Accepted for publication 7 October 1994

We have found that primary biliary cirrhosis (PBC) patients are unusually susceptible to recurrent urinary tract infections that are predominantly asymptomatic. The prevalence is $19 \%$ and the annual incidence is $35 \% .^{1}$ This is significantly greater than in either age matched women in a normal healthy population where the prevalence is $5 \%^{2}$ or in women with chronic liver diseases including different forms of chronic cholestasis $(7 \%)$ or rheumatoid arthritis (8\%). Furthermore, the recurrent infections found in patients with $\mathrm{PBC}$ are predominantly reinfections ${ }^{1}$ - that is, infections with a new bacterial species.

High titre antimitochondrial antibodies to one or more of the E2 components (dihydrolipoamide acyltransferases) of the 2-oxo-acid dehydrogenase complex family are present in the serum of $96 \%$ of patients. ${ }^{3-6}$ These mitochondrial enzymes are phylogenetically conserved so it is not surprising that antimitochondrial antibodies have been shown to cross react with a range of microorganisms. ${ }^{78}$

We have recently shown the presence of low titre antimitochondrial antibodies in the sera of a group of women with a history of recurrent urinary tract infection but with no evidence of liver disease. ${ }^{9}{ }^{10}$ On the basis of our results, we have proposed a molecular mimicry mech anism in the pathogenesis of PBC: a bacterial antigen, possibly resulting from recurrent urinary tract infections, may be responsible for initiating an autoimmune response in a predisposed host because of shared epitopes present on human tissue and bacteria. ${ }^{11}$

Thus, we wished to document the course of urinary tract infection in PBC. Firstly, we studied the natural history of significant bacteriuria in PBC patients on a weekly basis. Secondly, we undertook a randomised controlled pilot study to establish the effect of antibiotic treatment on asymptomatic bacteriuria. Thirdly, we compared the course of bacteriuria in asymptomatic patients with that of symptomatic patients, both groups being treated and followed in the same way. Finally we investigated if PBC patients without previous documented bacteriuria developed bacteriuria during a short follow up period.

\section{Patients and methods}

TREATMENT OF SYMPTOMATIC BACTERIURIA AND RANDOMISED TRIAL OF TREATMENT OF ASYMPTOMATIC BACTERIURIA

A sample of mid-stream urine (MSU) was obtained from 128 consecutive female PBC outpatients (appointments were usually three monthly) and any symptoms were recorded. None of these patients was receiving antimicrobial therapy. Symptomatic bacteriuria was defined as the presence of $10^{5}$ bacteria or more per $\mathrm{ml}$ of urine in patients complaining of dysuria, frequency and urgency of micturition, with or without loin pain or fever. All patients 
with symptomatic bacteriuria (group A; $n=13$ ) received a seven day course of either cotrimoxazole (two tablets twice daily) or amoxycillin ( $250 \mathrm{mg}$ three times daily) by mouth. The choice was determined by bacterial susceptibility and the patient's hypersensitivity. They were also given dipslides (Uricult, Orion), a well validated method for the culturing of urine, ${ }^{12}{ }^{13}$ with instructions how to inoculate them and a symptom questionnaire to return weekly to the laboratory.

Patients with asymptomatic bacteriuria $(n=25)$ were randomised consecutively without knowledge of clinical details of their liver disease, either to receive antimicrobial therapy (group $\mathrm{B} ; \mathrm{n}=14$ ) or to remain untreated (group $C ; n=11$ ). The patients allocated to receive treatment were sent a week's course of an oral antibiotic, dipslides, and symptom questionnaires. Dipslides and questionnaires were returned weekly. The bacteriuric patients in group $\mathrm{C}$ were asked to participate in a study involving regular checks on their urine without the patient knowing they had significant bacteriuria. They were also sent dipslides and questionnaires to return weekly. Any patient developing symptoms during the course of the study was treated as described for group A.

\section{SURVEY OF PBC PATIENTS WITHOUT PREVIOUS BACTERIOLOGICALLY PROVEN URINARY TRACT INFECTIONS}

Twenty six PBC patients (group D), diagnosed by standard criteria, ${ }^{14}$ and attending an outpatient clinic every three months were selected because hospital and general practitioner records showed the absence of infection in previous MSU specimens The MSU taken at the outpatient visit was also negative.

Each patient who satisfied these criteria was given 10 dipslides and asked to return one inoculated slide each week to the laboratory. We were thus able to investigate acquisition and spontaneous loss of bacteriuria between patients' three monthly clinic visits. Patients also reported any urinary symptoms present at the time of producing their weekly specimen.

These studies were approved by the Ethical Practices Committee of the Royal Free Hospital and were continued for one year.

\section{MICROBIOLOGY}

Quantitative white cell and bacterial counts were carried out on each MSU specimen.

TABLE I Comparability of groups $A, B$, and $C$

\begin{tabular}{lccc}
\hline & $\begin{array}{l}\text { Group A: } \\
\text { symptomatic/ } \\
\text { treated }\end{array}$ & $\begin{array}{l}\text { Group B: } \\
\text { asymptomatic/ } \\
\text { treated }\end{array}$ & $\begin{array}{l}\text { Group C: } \\
\text { asymptomaticl } \\
\text { not treated }\end{array}$ \\
\hline No of patients & 13 & 14 & 11 \\
Exclusions & 0 & 3 & 1 \\
No assessable & 13 & 11 & 10 \\
Median (range) age (y) & $57(38-69)$ & $65(42-80)$ & $54(38-69)$ \\
Total no of weeks of observation & 195 & 228 & 234 \\
Median (range) period of observation (wk) & $8(2-41)$ & $12(3-49)$ & $17(1-57)$ \\
No of treatment courses with antibiotics & 30 & 31 & NA \\
Median (range) bilirubin at outset ( $\mu$ mol/l) & $20(8-134)$ & $66(18-480)$ & $30(7-425)$ \\
Histological stage of disease: early/late & $5 / 8$ & $2 / 9$ & $5 / 5$ \\
\hline
\end{tabular}

NA= not applicable.
Dipslides were incubated at $37^{\circ} \mathrm{C}$ and their appearance was compared with a standard chart in order to make a semiquantitative assessment of the bacterial count. Specimens containing $10^{5}$ organisms or more $/ \mathrm{ml}$ of a single strain (or occasionally two strains) were regarded as indicating significant bacteriuria. Infecting organisms were identified by standard laboratory methods and antibiotic sensitivity patterns determined. Strains of Escherichia coli were O-serotyped and extended biotyping was carried out as previously described. ${ }^{15}$

\section{STATISTICAL ANALYSIS}

Differences between groups were analysed using the $\chi^{2}$ test and the Mann-Whitney U test. Where three groups were compared, Kruskal Wallis analysis of variance was used.

\section{Results}

TREATMENT OF SYMPTOMATIC BACTERIURIA AND RANDOMISED TRIAL OF TREATMENT OF ASYMPTOMATIC BACTERIURIA

All 13 patients in group A, 11 in group $B$ (three patients could not be assessed), and 10 in group C (one patient developed acute hepatic encephalopathy and had to be withdrawn from the study) were assessable. Patient details are compared in Table I.

The number of symptomatic reinfections in group A (10 of 14) was significantly greater than in group $B$ (two of 18), $p<0.001$ (Table II). An individual patient usually had either repeated symptomatic or repeated asymptomatic infections. The total numbers of infections treated in groups A and B were similar. In both groups, reinfections (new organisms) were more common than relapses (same organism) after treatment. There was no significant difference between the number of reinfections in the three groups $(p>0.05)$ or the number of relapses in groups $A$ and $B$ $(\mathrm{p}>0.05)$.

Symptoms described by the patients were similar to those described by patients with urinary tract infections who were otherwise healthy. Frequency, dysuria, and urgency were common; pyrexia and loin pain were reported by only one PBC patient. One symptom that seemed to be specific to the PBC group was an increase in vaginal irritation associated with the onset of infection. PBC patients have dry epithelial surfaces which may cause the irritation, urinary tract infections seem to exacerbate the problem.

The median interval between episodes of infection was similar and did not differ significantly between the two groups (group A, three weeks; group $B$, four weeks; $p=0.47$ ) (Table II).

Most of the patients in group $\mathrm{C}$ cleared their bacteriuria spontaneously; they usually became reinfected with a new strain. One patient, however, remained bacteriuric with the same organism for 22 weeks. Cumulative analysis of the data showed that these patients 
TABLE II Summary of results of screening for bacteriuria by dipslide examination, in patients with serious baseline bacteriuria

\begin{tabular}{|c|c|c|c|}
\hline & $\begin{array}{l}\text { Group A: } \\
\text { symptomaticl } \\
\text { treated }\end{array}$ & $\begin{array}{l}\text { Group B: } \\
\text { asymptomaticl } \\
\text { treated }\end{array}$ & $\begin{array}{l}\text { Group } C: \\
\text { asymptomaticl } \\
\text { not treated }\end{array}$ \\
\hline $\begin{array}{l}\text { No of patients } \\
\text { Total no of bacteriuric weeks } \\
\text { Total no of separate bacteriuric episodes } \\
\text { Reinfections } \\
\text { Symptomatic/asymptomatic } \\
\text { Relapses (range) } \\
\text { Median (range) interval between infective } \\
\text { episodes (wk) } \\
\text { Median (range) length of bacteriuric episode } \\
\text { (wk) } \\
\text { Median (range) rate of increase of bilirubin } \\
(\mu \mathrm{mol} / \mathrm{m} / \mathrm{mth})\end{array}$ & $\begin{array}{l}13 \\
\text { NA } \\
30 \\
14 \\
10 / 4 \\
6 \\
3(2-22) \\
\text { NA } \\
0.65(0-10 \cdot 8)\end{array}$ & $\begin{array}{l}11 \\
\text { NA } \\
31 \\
18 \\
2 / 16 \\
7 \\
4(2-31) \\
\text { NA } \\
0 \cdot 46(0-7 \cdot 3)\end{array}$ & $\begin{array}{l}10 \\
179(76 \%) \\
22 \\
12 \\
2 / 10 \\
\mathrm{NA} \\
\quad 2(0-10) \\
3(1-42) \\
0 \cdot 48(0-66 \cdot 2)\end{array}$ \\
\hline
\end{tabular}

$\mathrm{NA}=$ not applicable.

were bacteriuric for $76 \%$ of the observation period (179 of 234 weeks). The median interval between bacteriuric episodes was two weeks, significantly shorter than in the asymptomatic treated group $(p=0 \cdot 046)$. However, when group $\mathrm{C}$ was compared with group A (the symptomatic treated group), the median interval was not significant. Using Kruskal Wallis analysis of variance, there was no significant difference in the interval between infective episodes for the three groups. The median length of each untreated bacteriuric episode was three weeks. In group $\mathrm{C}$, only two of 10 patients developed symptoms during the first few weeks of observation and were treated. Of the remaining 20 episodes of infection, only three $(15 \%)$ were associated with symptoms and were subsequently treated.

Combining groups A, B, and C, $21(62 \%)$ patients experienced more than one infection: nine $(69 \%)$ in group $\mathrm{A}$, seven $(64 \%)$ in group $B$, and five $(50 \%)$ in group C (Table III). Infecting organisms were similar in each group. $E$ coli was the most common pathogen, accounting for $72 \%$ of all infections, and serotypes were similar. The occurrence of significant pyuria (10 white blood cells or more $/ \mathrm{mm}^{3}$ ) in infected urines was similar and did not differ significantly in each group. However, only 47 infected urines could be tested for pyuria (this is not possible with dipslide specimens), which was present in seven of eight urines in group A $(88 \%), 10$ of 20 urines in group B (50\%), and 13 of 19 $(68 \%)$ in group $\mathrm{C}$.

TABLE III Number of infective episodes

\begin{tabular}{llll}
\hline & $\begin{array}{l}\text { Group A: } \\
\text { symptomaticl } \\
\text { treated } \\
(n=13)\end{array}$ & $\begin{array}{l}\text { Group B: } \\
\text { asymptomaticl } \\
\text { treated } \\
(n=11)\end{array}$ & $\begin{array}{l}\text { Group C: } \\
\text { asymptomaticl } \\
\text { not treated } \\
(n=10)\end{array}$ \\
\hline No of infections per patient & & & \\
1 & 4 & 4 & 5 \\
2 & 5 & 3 & 2 \\
3 & 1 & - & - \\
4 & 2 & - & 2 \\
5 & 1 & 1 & - \\
6 & - & - & - \\
7 & - & 1 & - \\
8 & - & 31 & 1 \\
9 & - & 2 & $2 \cdot 2$ \\
Total no of infections & 30 & $2 \cdot 8$ & \\
Median no of infections/patient & 2 & & \\
Mean no of infections/patient & $2 \cdot 3$ & & \\
\hline
\end{tabular}

PBC PATIENTS WITHOUT PREVIOUS BACTERIOLOGICALLY PROVEN URINARY

TRACT INFECTIONS

Seven $(29 \%)$ of the 24 assessable patients (two consistently produced contaminated specimens and were excluded) developed significant bacteriuria during the three month study. In three patients infections were symptomatic and they were treated with cotrimoxazole for seven days. These infections appeared at five and nine weeks for one and two patients respectively. Four patients developed asymptomatic bacteriuria at intervals of two, four, seven, and nine weeks respectively, that cleared spontaneously within two to four weeks of onset. Five of the seven patients were in the late stage of PBC as judged by histological criteria. ${ }^{14}$

\section{Discussion}

Untreated asymptomatic PBC patients cleared their bacteriuria spontaneously, but were usually rapidly reinfected with a different organism. Treatment of bacteriuric episodes did not change the pattern of bacteriuria in these patients. Symptomatic and asymptomatic infections which were treated, followed a similar course in terms of the median interval between successive infective episodes and the number of relapses and reinfections (Table II). In normal women it has been suggested that treatment of asymptomatic bacteriuria can result in reinfection by more virulent organisms leading to symptomatic infection. ${ }^{13}$ Our results show that this does not occur in PBC patients. Asymptomatic patients (group B) developed mainly asymptomatic reinfections $(89 \%)$ after treatment, whereas the symptomatic patients (group A) developed mainly symptomatic reinfections (71\%). However, the bacteria causing symptomatic and asymptomatic infections were of similar species ( $E$ coli of similar serotype and biotype).

Symptomatic patients clearly need treatment to relieve symptoms. However, repeated treatment of single asymptomatic or symptomatic bacteriuric episodes seems to have only short term benefit, as sterile urine in PBC patients is achieved for periods no longer than three to four weeks. Whether asymptomatic bacteriuria, if left untreated, leads to infection of the upper urinary tract and kidneys is unclear. In our previous study ${ }^{16}$ tests for antibody coated bacteria were positive in 41 $(49 \%)$ of 89 PBC patients with untreated asymptomatic bacteriuria. However, the antibody coated bacteria test does not reliably indicate upper tract involvement so that further studies of the localisation of urinary infection are needed before embarking on regular screening and treatment of infections.

We found that $29 \%$ of 24 PBC patients without previous bacteriologically proved urinary tract infections, developed bacteriuria within three months, and that these patients become bacteriuric and spontaneously a bacteriuric over short periods of time. This pattern contrasts with asymptomatic bacteriuria in pregnant women, who have an 
extremely low spontaneous cure rate during pregnancy. ${ }^{17}$ Previous studies on the natural history of asymptomatic bacteriuria in apparently healthy women which involved screening of MSUs at $\operatorname{six}^{18}$ or three monthly intervals, ${ }^{19}$ showed that spontaneous cure was common. More frequent screening has not been reported.

Although bacteriuria in PBC has been shown to be independent of other prognostic variables such as age, serum bilirubin, ascites, and cirrhosis it nevertheless defines a specific subgroup of patients with an increased risk of death. ${ }^{20}$ Although we have now shown an increased incidence of recurrent urinary tract infection in PBC in two different sets of patients, ${ }^{19}$ two other groups have been unable to find a difference in the prevalence of urinary tract infection between PBC and other groups. ${ }^{21} 22$ In one of these studies, however, a striking increase was shown in the cumulative proportion of samples with significant bacteriuria over a six month follow up period compared with controls, which suggests an increase in recurrent bacteriuria. ${ }^{21}$ In the other study, which evaluated only the prevalence of urinary tract infection, cirrhotics being assessed in hospital for liver transplantation were evaluated in the late stages of cirrhosis ${ }^{22}$; it is possible that no differences exist between different aetiologies in the late stages of disease.

We have suggested that molecular mimicry between a foreign and self antigen may be important in the pathogenesis of PBC. Our recent finding of low titre PBC specific antimitochondrial antibodies in the serum of healthy females with recurrent urinary tract infection but no liver disease supports this hypothesis. ${ }^{910}$ Data from the current study show that women with PBC have infected urine for considerable periods of time. These recurrent urinary tract infections may constantly activate the immune system and might therefore stimulate helper $T$ cells to recognise the immunogenic region of $E$ coli $\mathrm{E} 2$, the result being a polyclonal antibody response to infecting immunogens. An autoimmune response could later arise when helper $\mathrm{T}$ cells, originally stimulated by microbial E2, go on to recognise cross reactive epitopes on human tissue. ${ }^{11}$

In conclusion, this study shows that women with PBC have repeatedly infected urine for extended periods of time. Episodic treatment of asymptomatic bacteriuria does not lead to prolonged periods of freedom from infection as the reinfection rate is similar to untreated asymptomatic patients. Bacteriuria does not seem to affect the patient in the short term. A randomised trial of low dose long term prophylactic therapy compared with placebo may define the long term effects of bacteriuria on the prognosis and course of PBC and also define its relationship to the disease. If molecular mimicry does play a role in the pathogenesis of $\mathrm{PBC}$, long term prophylaxis may be advantageous, in that elimination or reduction of gut flora might help in modulating autoimmunity.

We thank Dr Isobel Rosenstein for coordinating the study and NETRHA for partial financial support.

1 Burroughs AK, Rosenstein IJ, Epstein O, Hamilton-Miller JMT, Brumfitt W, Sherlock S. Bacteriuria and primary biliary cirrhosis. Gut 1984; 25: 133-7.

2 Evans DA, Williams DN, Laughlin LW, Miao L, Warren JW, Hennekens $\mathrm{CH}$ et al. Bacteriuria in a populationbased cohort of women. $\mathcal{F}$ Inf Dis $1978 ; 138: 768-73$.

3 Kaplan MM. Primary biliary cirrhosis. N Engl f Med 1987; 316: $521-8$.

4 Gershwin ME, Mackay IR, Surgess A, Coppel RL. Identification and specificity of a cDNA encoding the $70 \mathrm{kD}$ mitochondrial antigen recognised in primary biliary cirrhosis. F Immunol 1987; 138: 3525-31.

5 Yeaman SJ, Fussey SPM, Danner DJ, James OFW, Multimer DJ, Bassendine MF. Primary Biliary Cirrhosis: identification of two major M2 mitochondrial autoantigens. Lancet 1988; i: 1067-70.

6 Fussey SPM, Guest JR, James OFW, Bassendine MF, Yeaman SJ. Identification and analysis of the major M2 autoantigens in primary biliary cirrhosis. Proc Natl Acad Sci USA 1988; 85: 8654-8.

7 Baum H. Nature of the mitochondrial antigens of primary biliary cirrhosis and their possible relationships to the etiology of the disease. Sems Liv Dis 1989; 9: 117-21.

etiology of the disease. Sems Liv Dis 1989; 9: 117-21.
8 Flannery GR, Burroughs AK, Butler P, Chelliah J, Hamilton-Miller JMT, Brumfitt W, et al. Antimitochondrial antibodies in primary biliary cirrhosis recognise both specific peptides and shared epitopes of the M2 family of antigens. Hepatology 1989; 10: 370-4.

9 Butler P, Valle F, Hamilton-Miller JMT, Brumfitt W, Baum $\mathrm{H}$, Burroughs AK. M2 mitochondrial antibodies and urinary rough mutant bacteria in patients with primary biliary cirrhosis and in patients with recurrent bacteriuria. f Hepatol 1993; 17: 408-14.

10 Butler P. Hamilton-Miller JMT, Baum H, Burroughs AK. PBC specific M2 autoantibodies in patients with recurrent urinary tract infection using an ELISA and purified pyruurinary tract infection using an ELLSA and purified
vate dehydrogenase. Gut 1993; 34 (suppl 1): S30.

11 Burroughs AK, Butler P, Sternberg M, Baum H. Molecular mimicry in liver disease. Nature 1992; 358: 377-78.

2 Kunin CM. Detection, prevention and management of urinary tract infections. 4th ed. Philadelphia: Lea \& Fabiger, 1987.

13 Asscher AW. The challenge of urinary tract infections. London: Academic Press, 1980.

14 Sherlock S, Scheuer PJ. The presentation and diagnosis of 100 patients with primary biliary cirrhosis. $N$ Engl $\mathcal{F}$ Med 1973; 389: 674-7.

15 Gargan RA, Brumfitt W, Hamilton-Miller JMT. A concise biotyping system for differentiating strains of Escherichia biotyping system for differentiating
coli. $₹$ Clin Pathol 1982; 35: 1366-9.

16 Rosenstein IJ, Burroughs AK. Bacteriuria and primary biliary cirrhosis. In: Asscher AW, Brumfitt W, eds. Microbial diseases in nephrology. Chichester: John Wiley, 1986: 125-35.

17 Whalley PJ, Martin FG, Peter PC. Significance of asymptomatic bacteriuria detected during pregnancy. $\mathcal{F} A M A$ 1965; 193: 879-81.

18 Asscher AW, Sussman M, Waters WE, Evans JAS, Campbell H, Evans KT, et al. Asymptomatic significant bacteriuria in the non-pregnant woman. II. Response to treatment and follow-up. BMF 1969; i: 804-6.

19 Olling S, Verrier-Jones K, Mackenzie R, Verrier-Jones ER, Hanson LA, Asscher AW. A four year follow up of school girls with untreated covert bacteriuria: bacteriological girls with untreated covert bacteriuria:

20 Morreale M, Tsirigotis M, Hughes MD, Brumfitt W, McIntyre N, Burroughs AK. Significant bacteriuria has prognostic significance in primary biliary cirrhosis. f Hepatol 1989; 9: 149-58.

21 Floreani A, Bassendine MF, Mitchison H, Freeman R, James OFW. No specific association between primary biliary cirrhosis and bacteriuria? $\mathcal{F}$ Hepatol 1989; 8: 201-7.

22 Rabinovitz M, Prieto M, Gavaler JS, Van Thiel DH. Bacteriuria in patients with cirrhosis. $\mathcal{f}$ Hepatol 1992; 16: 73-6. 